\title{
BIOAKTIVITAS ASAM JAWA (Tamarindus indica) DAN PEMANFAATANNYA
}

\author{
Marina Silalahi \\ Prodi Pendidikan Biologi, Fakultas Keguruan dan Ilmu Pendidikan, Universitas Kristen Indonesia \\ Email: marina.silalahi@uki.ac.id
}

\section{Diterima 12 September 2020 disetujui 13 Okober 2020 diterbitkan 15 November 2020}

\begin{abstract}
Tamarindus indica is one of the species in the Fabaceae which is widely used as food and traditional medicine. T. indica has naturalized in Indonesia, especially in Java Island and mostly only used as food, while its use as medicine is still limited. This study aims to explain the relationship between the use of T. indica as a traditional medicine and its bioactivity. The method used in this study is based on literature studies obtained online using the key word Tamarindus indica, uses of T. indica and bioactivities of T. indica. The use of T. indica as a traditional medicine is related to its bioactivity. Bioactivity of $T$. indica as antimicrobial, antidiabetic mellitus, anti-cholesterol, analgesic, antiobesity and antioxidant. Bioactivity of T. indica as anti-microbial and anticancer has the potential to be developed as a food preservative as well as providing healthy effects.
\end{abstract}

Keywords: Tamarindus indica, antimicrobial, anticancer

\section{PENDAHULUAN}

Tamarindus indica atau yang sering dikenal dengan nama asam Jawa merupakan salah satu tumbuhan multifungsi yang banyak ditemukan di Indonesia terutama di Pulau Jawa. Pemberian nama asam Jawa pada tanaman ini diduga berhubungan dengan rasa buahnya yang asam dan banyak ditemukan di Pulau Jawa. Secara empirik terlihat, bahwa $T$. indica banyak ditemukan di Jakarta dan sekitarnya seperti di pinggir jalan raya, taman kota, pekarangan dan kebun masyarakat. Silalahi dan Mustaqim (2020) menyatakan bahwa $T$. indica merupakan tanaman asli di Afrika, namun telah ternaturalisasi di Indonesia terutama di Pulau Jawa.

Masyarakat lokal Indonesia telah lama memanfaatkan $T$. indica untuk berbagai keperluan seperti bahan arang, kayu bakar, obat tradisional, dan bahan pangan. Jamu kunir asam (kunir= kunyit; asam $=T$. indica) merupakan minuman kesehatan tradisional etnis Jawa yang dibuat dari bahan utama estrak segar buah T. indica dan rhizoma Curcuma longa (Nahdi and Kurniawan 2019; Sumarni et al. 2019). Selain digunakan sebagai bahan jamu, buah $T$. indica dalam pengolahan sayur asem. Sayur asem merupakan salah satu makanan atau sayur tradisional etnis Betawi yang dengan memanfaatkan daun dan biji melinjo (Gnetum gnemon sebagai bahan utama) (Silalahi 2020) dan buah $T$. indica sebagai bumbu utamanya. Buah segar $T$. indica juga merupakan salah satu komoditis yang telah lama diperjualbelikan di pasar tradisional maupun pasar modern.

Pulp buah $T$. indica memiliki rasa asam yang menyenangkan dan aroma yang kaya, dan karenanya, digunakan sebagai bahan utamanya agen asam untuk kari, saus, dan minuman (Obulesu dan Bhattacharya 2011). Penambahan ekstrak pulp buah $T$. indica pada berbagai makanan maupun minuman memberi efek yang menyegarkan serta memberi aroma yang khas sehingga meningkatkan cita rasanya. Buah $T$. indica memiliki rasa asam manis berhubungan dengan kandungan yang tinggi asam tartarat dan gula pereduksi (De Caluwé et al 2010). Komersial minuman $T$. indica berbasis asam tersedia di banyak negara. Kandungan vitamin B cukup tinggi, kandungan karoten dan vitamin $\mathrm{C}$ rendah. Daun T. indica merupakan sumber vitamin 
C dan $\alpha$-karoten dan juga memiliki kandungan mineral adalah tinggi, terutama P, K, Ca dan Mg (De Caluwé et al 2010).

Selain digunakan sebagai bahan pangan, $T$. indica juga digunakan sebagai obat tradisional. Buah $T$. indica oleh suku Benin dimanfaatkan sebagai pencahar, kulit kayunya mengobati luka sedangkan daunnya digunakan sebagai antibiotik (Fandohan et al 2010). Kuru (2014) melaporkan bahwa $T$. indica digunakan untuk mengatasi sakit perut, diare, disentri beberapa infeksi bakteri, mengatasi luka, konstifasi dan inflamasi. Di Indonesia, laporan pemanfaatan $T$. indica sebagai obat tradisional sangat terbatas, padahal potensi tanaman ini sangat banyak. Pemanfaatan bahan alam sebagai obat relative lebih aman dibandingkan dengan obat sintesis, namun perlu pemahaman yang memadai sehingga efek samping dari penggunaan bahan alam dapat diminimlaisi. Nwodo et al (2011b) menyatakan bahwa $T$. indica digunakan sebagai makanan dan obat telah terbukti beracun pada dosis tinggi (Nwodo et al 2011b). Kajian ini bertujuan menjelaskan hubungan pemanfaatan dan bioaktivitas $T$. indica sehingga diperoleh informasi yang mendalam untuk pengembangan obat tradisional.

\section{METODE}

Penulisan artikel ini didasarkan pada kajian literature pada berbagai hasil penelitian yang terbit secara online. Beberapa sumber yang digunakan adalah google scholar, pubmed dengan menggunakan kata kunci Tamarindus indica, uses of $T$. indica serta bioactivities $T$. indica. Informasi yang diperoleh disintesakan sehingga dapat menjelaskan manfaat dan biaoktivitas $T$. indica.

\section{HASIL DAN PEMBAHASAN 1. Botani Tamarindus indica}

Tamarindus indica merupakan salah satu species dari famili Fabaceae yang telah lama dimanfaatkan masyarakat lokal di Indonesia maupun negara lain. Fabaceae merupakan family terbesar kedua tumbuhan obat dan diperkirakan 490 species digunakan sebagai obat tradisional (Gao et al 2010). Tamarindus indica berupa pohon, $25 \mathrm{~m}$, diameter batang hingga $1 \mathrm{~m}$. Kulit batang saat tua berwarna coklat, pecah dan luruh seperti sisik. Daun: Daun majemuk menyirip genap dan didukung oleh daun penumpu yang kecil. Daun penumpu cepat gugur. Panjang tangkai dan rakis daun 5 $16 \mathrm{~cm}$, anak daun $10-20$ pasang, jorong, panjang $8-30 \mathrm{~cm}$ dan lebar $3-10 \mathrm{~mm}$. Pangkal helaian membundar dengan ujung yang juga membundar atau sedikit bertusuk. Bunga: Perbungaan tandan. Panjang rangkaian perbungaan hingga 22 $\mathrm{cm}$. Bunga dengan simetri tunggal, kelopak berjumlah 4 , jorong, panjang $8-12 \mathrm{~mm}$, mahkota 3 helai dengan ukuran yang berbeda. Segmen mahkota bundar telur, panjang $10-13$ dan lebar $2-6 \mathrm{~mm}$ (Gambar 1A). Benang sari kurang dari 10 dan dengan kepala sari fertil berjumlah 3 dan steril berjumlah 4 atau 5. Bakal buah menumpang dan dengan bakal biji berjumlah antara $8-14$. Buah dan Biji: Buah bertipe polong yang tidak pecah. Polong berbentuk lonjong dengan panjang 5 - $15 \mathrm{~cm}$ dan lebar $1-3 \mathrm{~cm}$ (Gambar 1B). Daging buah lembek dan berasa masam atau agak manis. Warna daging buah coklat pucat. Biji per polong dengan jumlah hingga 10, berbentuk bundar telur sungsang-membundar dan memipih. Panjang biji antara $11-17 \mathrm{~mm}$ dan lebar 10 - $12 \mathrm{~mm}$ (Silalahi dan Mustaqim 2020). 

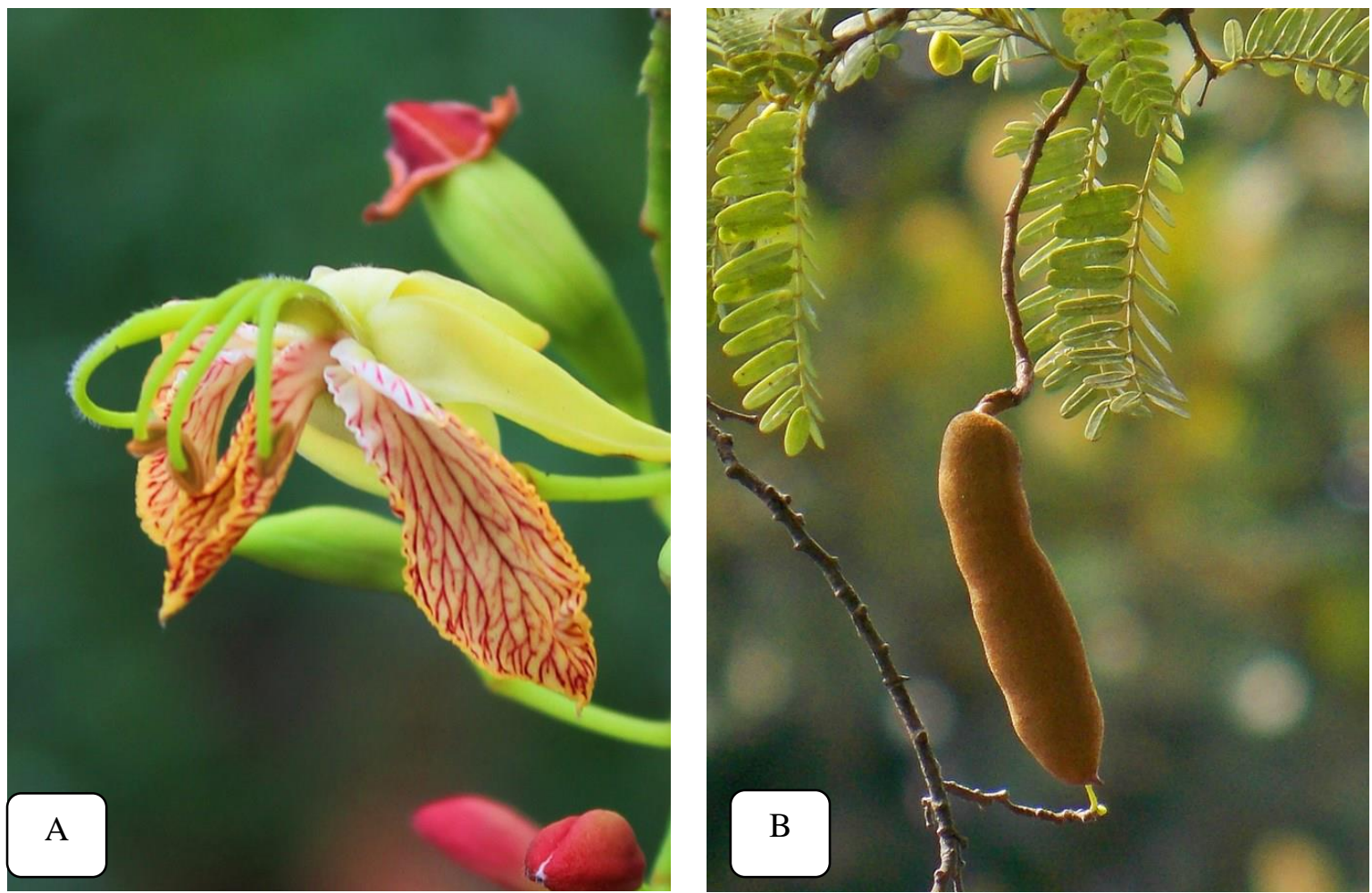

Gambar 1. Asam Jawa atau Tamarindus indica. A. Bunga mekar penuh. B. Buah polong

\section{Manfaat Dan Bioaktivitas}

Tamarindus indica telah lama digunakan oleh berbagai etnis di Indonesia maupun di dunia sebagai obat tradisional. Kuru (2014) melaporkan bahwa $T$. indica digunakan untuk mengatasi sakit perut, diare, disentri beberapa infeksi bakteri, mengatasi luka, konstifasi dan inflamasi (Kuru 2014). Pemanfaatan $T$. indica sebagai obat tradisional berhubungan dengan bioaktivitasnya. Berikut ini akan dijelaskan lebih lanjut bioaktivitas $T$. indica sebagai antimikroba, antidiabetes mellitus, antikolesterol, analgesik, antiobesitas dan antioksidan.

\subsection{Antimikroba}

Senyawa antimikroba merupakan senyawa yang mengakibatkan kematian mikroba atau menghambat pertumbuhannya, oleh karena itu senyawa antimikroba banyak digunakan untuk mengatasi penyakit yang disebabkan infeksi mikroba. Di sisi lain senyawa antimikroba dapat juga digunakan sebagai pengawet makanan. Kuru (2014) menyatakan bahwa $T$. indica telah lama digunakan untuk mengatasi berbagai penyakit yang diakibatkan oleh mikroba seperti sakit perut, diare, disentri beberapa infeksi bakteri, mengatasi luka. T. indica yang digunakan dalam pengobatan tradisional untuk pengobatan flu, demam, gangguan lambung, diare dan penyakit kuning dan pembersih kulit (Doughari 2006). Biaoktivitas T. indica sebagai antimikroba memiliki prospek pegembangan anti mikroba baru untuk pengendalian penyakit infeksi (Gumgumjee et al 2012).

Ekstrak etanol dan air (panas dan dingin) dari bubur buah, kulit batang dan daun $T$. indica memiliki aktivitas antibakteri, in vitro, terhadap bakteri Gram negatif dan Gram positif (Nwodo et al 2011). Ekstrak kulit buah T. indica menghambat pertumbuhan bakteri Staphylococcus aureus, Escherichia coli (Prabhu et al 2014), sedangkan ekstrak daunnya menghambat pertumbuhan Klebsiella pneumoniae, Micrococcus luteus, Pseudomonas aeruginosa, Staphylococcus aureus (Gumgumjee et al 
2012), ekstrak buah menghambat pertumbuhan Salmonella paratyphi, Bacillus subtilis, Salmonella typhi dan Staphylococcus aureus (Doughari 2006). Ekstrak air pulp buah $T$. indica memiliki sensivitas yang berbeda-beda terhadap bakteri yaitu Staphylococcus aureus > Escherichia coli > Pseudomonas aeruginosa namun tidak sensitif terhadap Salmonella typhi (Abubakar et al 2008).

Bioaktivitas anti bakteri berhubungan dengan kandungan glikosida flavanoid berupa orientin dan vitexin (Gumgumjee et al 2012). Ekstrak berair dan organik (aseton dan etanol) buah $T$. indica mengandung tanin, saponin, sesquiterpen, alkaloid dan phlobatamins memiliki aktivitas terhadap bakteri gram positif dan bakteri gram negative (Doughari 2006). Ekstrak air pulp buah $T$. indica mengandung saponin, alkaloid dan glikosida (Abubakar et al 2008).

\subsection{Antidiabetes Mellitus}

Diabetes mellitus merupakan penyakit yang disebabkan ganguan metabolisme yang menyebabkan kadar glukosa serum darah di atas normal atau sering juga disebut dengan hiperglikemia. Shahraki et al (2011) menyatakan bahwa $T$. indica digunakan sebagai pengobatan tradisional untuk diabetes mellitus. Pemberian ekstrak air biji $T$. indica mencegah peningkatan insulin serum saat puasa, trigliserida, kolesterol total, lipoprotein densitas sangat rendah, lipoprotein densitas rendah, pada kelompok kelompok tikus yang diberi fruktosa yang diolah dengan dan ekstrak T. indica. Suplementasi ekstrak $T$. indica mungkin memperbaiki sindrom metabolik karena peningkatan insulin (Shahraki et al 2011). Dosis tunggal dan multidosis ekstrak kulit biji hidroetanol $T$. indica secara signifikan mengurangi kadar glukosa darah pada normoglikemik dan kadar glukosa pada hewan hiperglikemik yang diinduksi dengan aloksan. Ekstrak kulit biji hidroetanol $T$. indica memberi efek perlindungan pada sel $\beta$ pankreas hewan percobaan. Peningkatan ekstrak kulit biji hidroetanol T. indica juga akan meningkatkan penyerapan glukosa pada hemi-diafragma tikus dan mencegah penurunan berat badan (Bhadoriya et al 2017).

\subsection{Antikolesterol}

Modifikasi diet dapat secara signifikan mengurangi faktor risiko penyakit kardiovaskular, termasuk kolesterol dan aterosklerosis (Martinello et al 2006). Pulp kering dan bubuk buah $T$. indica, dengan dosis $15 \mathrm{mg} / \mathrm{kg}$ tubuh berat badan, ditemukan mengurangi kadar kolesterol total dan kadar kolesterol lipoprotein low density secara signifikan (Iftekhar et al 2006). Pengobatan hamster hiperkolesterolemia dengan pulp ekstrak buah T. indica (5\%) menyebabkan penurunan kadar kolesterol total serum (50\%), kolesterol non-high density lypoprotein $(73 \%)$ dan trigliserida $(60 \%)$, dan untuk peningkatan kadar kolesterol high-density lipoprotein (61\%) (Martinello et al 2006). Ekstrak metanol bubur buah $T$. indica mengubah ekspresi gen lipid seperti ABCG5 dan APOAI dalam sel HepG2 (Chong et al 2012).

\subsection{Analgesik}

Senyawa analgesik merupakan senyawa yang berfungsi mengurangi rasa nyeri yang ditimbulkan karena adanya peradangan di dalam tubuh. Di laboratorium, efek analgesik dievaluasi menggunakan tes menggeliat yang diinduksi asam asetat, hot plate dan formalin. Ekstrak air buah T. indica (60$600 \mathrm{mg} / \mathrm{kg}$ ) secara signifikan menghambat aktivitas menggeliat yang tergantung pada dosis dengan persentase analgesik tercatat antara 51,8 dan 74,1 (Khalid et al 2010).

\subsection{Antikanker}

Tumbuhan yang digunakan sebagai antikanker merupakan tumbuhan yang menghasilkan senyawa yang menghambat pembelahan sel. Fraksi ekstrak etanol buah $T$. indica menunjukkan aktivitas sitotoksik yang jelas melawan sel-sel embrio landak laut. L - (-) - di- pentenyl malate 
merupakan senyawa penghambat paling efektif untuk dalam perkembangan telur yang telah dibuahi (Kobayashi et al 1996). PST001 yang diisolasi dari biji $T$. indica memiliki nilai IC50 pada line sel kanker A549, KB, dan DLA sebesar 80,72, 190,99, dan $91,14 \mu \mathrm{g} / \mathrm{mL}$ secara berurutan. Pengurangan tumor diperoleh pada tumor DLA dan EAC pada pengobatan dengan PST001 yang lebih menonjol ketika PST001 diberikan dengan CTX/5fluorouracil (Aravind et al 2012).

\subsection{Antiobesitas}

Obesitas dan kelebihan berat badan banyak dikaitkan dengan aterosklerosis, hati berlemak, hiperlipemia, diabetes mellitus, dan kanker, oleh karena itu mengurangi obesitas secara tidak langsung akan mengurangi resiko terhadap penyakit lainnya. Tikus yang diberi ekstrak air $T$. indica 5, 25, dan 50 selama 10 minggu, yang sebelumnya telah diinduksi obesitas melalui diet tinggi lemak menurunkan kadar kolesterol total plasma, low-density lipoprotein, dan trigliserida, dan meningkat high-density lipoprotein, bersamaan dengan pengurangan berat badan (Azman et al 2012). Ekstrak air T. indica menurunkan plasmaleptin dan mengurangi aktivitas sintase asam lemak dan meningkatkan efisiensi pertahanan antioksidan sistem. Ekstrak air $T$. indica menunjukkan efek antiobesitas yang ditunjukkan dengan pengurangan yang signifikan dalam bobot jaringan adiposa, serta menurunkan derajat steatosis hati pada tikus obesitas yang diinduksi Azman et al 2012).

\subsection{Antioksidan}

Radikal bebas menyebabkan terjadinya ketidakstabilan electron di dalam tubuh yang mengakibatkan stress oksidatif yang secara langsung maupun tidak langsung berdampak pada berbagai penyakit seperti stroke, diabetes mellitus. Senyawa yang menghambat stres oksidatif disebut dengan antioksidan. Razali et al (2012) menyatakan bahwa terdapat korelasi positif antara kandungan fenolik dan aktivitas antioksidan yang dihasilkan tanaman. Ekstrak etanol biji $T$. indica menunjukkan kandungan total karbohidrat yang tinggi dan memiliki kandungan fenolik yang memiliki aktivitas antioksidan (Luzia dan Jorge 2011). Ekstrak biji $T$. indica dengan menggunakan pelarut yang berbeda-beda memiliki aktivitas yang berbeda yang dihubungkan dengan kandungan senyawa fenoliknya. Senyawa fenolik dari biji dengan pelarut methanol lebih besar dibandingkan dengan etil asetat dan heksana. Kandungan fenolik ekstrak berkisar 3,17-309 mg setara asam galat/g. Analisis HPLC dari ekstrak methanol daun $T$. indica mengandung katekin, epicatechin, quercetin dan isorhamnetin (Razali et al 2012). Secara in vitro, ekstrak T. indica tersebut menunjukkan kemampuan pembersihan radikal, seperti yang dinilai oleh 2,2-difenil-1-pikrillhidrazil (DPPH) dan superoksidates radikal, dan menyebabkan penurunan peroksidasi lipid alam serum, sebagaimana dinilai oleh zat reaktif asam thiobarbituric pengujian kadar logam. In vivo, ekstrak meningkatkan efisiensi sistem pertahanan antioksidan, seperti yang dinilai oleh superoksida dismutase, katalase dan aktivitas glutation peroksidase. Hal tersebut menunjukkan potensi ekstrak asam dalam mengurangi risiko aterosklerosis pada manusia (Martinello et al 2006).

\section{SIMPULAN}

Pemanfaatan $T$. indica sebagai obat tradisional berhubungan dengan bioaktivitasnya. Bioaktivitas T. indica sebagai antimikroba, antidiabetes mellitus, antikolesterol, analgesik, antiobesitas dan antioksidan. 


\section{DAFTAR PUSTAKA}

Aravind, S.R., Joseph, M.M., Varghese, S., Balaram, P. and Sreelek, T.T. (2012). Antitumor and immunopotentiating activity of polysaccharide PST001 isolated from the seed kernel of Tamarindus indica: an in vivo study in mice. The Scientific World Journal ID 361382, 14 pages doi:10.1100/2012/361382

Azman, K.F., Amom, Z., Azlan, A., Esa, N.M., Ali, R.M., Shah, Z.M. and Kadir, K.K.A. (2012). Antiobesity effect of Tamarindus indica L. pulp aqueous extract in high-fat diet-induced obese rats. $J$ Nat Med. DOI 10.1007/s11418-0110597-8

Abubakar, M.G., Ukwuani, A.N. and Shehu, R.A. (2008). Phytochemical screening and antibacterial activity of Tamarandus indica pulp extract. Asian Journal of Biochemistry 3(2): 134-138.

Bhadoriya, S.S., Ganeshpurkar, A., Bhadoriya, R.P.S., Sahu, S.K., and Patel, J.R. (2017). Antidiabetic potential of polyphenolic-rich fraction of Tamarindus indica seed coat in alloxan-induced diabetic rats. $J$ Basic Clin Physiol Pharmacol doi.org/10.1515/jbcpp2016-0193: 1-9

Chong, U.R.W., Abdul-Rahman, P.S., Abdul-Aziz, A., Hashim, O.H., Junit, M.S. (2012). Tamarindus indica extract alters release of alpha enolase, apolipoprotein A-I, transthyretin and rab GDP dissociation inhibitor beta from HepG2 cells. Plos One 7(6): e39476.

doi:10.1371/journal.pone.0039476

De Caluwé, E., Halamová, K., van Damme, P. (2010). Tamarindus indica L. A review of traditional uses, phytochemistry

and pharmacology. Afrika Focus 23(1): 53-83.

Doughari, J.H. (2006). Antimicrobial activity of Tamarindus indica Linn. Tropical Journal of Pharmaceutical Research 5(2): 597-603.

Gumgumjee, N.M., Khedr, A. and Hajar, A.S. (2012). Antimicrobial activities and chemical properties of Tamarindus indica L. leaves extract. African Journal of Microbiology Research 6(32): 6172-6181.

Gao, T., Yao, H., Song, J., Liu, C., Zhu, Y., Ma, X., Pang, X., Xu, H. and Chen, S. (2010). Identification of medicinal plants in the family Fabaceae using a potential DNA barcode ITS2. Journal of Ethnopharmacology 130:116-121.

Iftekhar, A.S.M.M., Rayhan, I., Quadir, M.A., Akhteruzzaman, S. and Hasnat, A. (2006). Effect of Tamarindus indica fruits on blood pressure and lipid-profile in human model: an in vivo approach. Pak. J. Pharm. Sci. 19(2): 125-129.

Khalid, S., Mossadeq, W.M.S., Israf, D.A., Hashim, P., Rejab, S., Shaberi, A.M., Mohamad, A.S., Zakaria, Z.A. and Sulaiman, M.R. (2010). In vivo analgesic effect of aqueous extract of Tamarindus indica L. fruits. Med Princ Pract 19: 255259.

Kobayashi, A., Adenarr, M.I., Kajiyama, S., Kanzaki, H. and Kawazu, K. (1996). Cytotoxic principle of Tamarindus indica, di-w-butyl Malate and the structure-activity relationship of its analogues. $\mathrm{Z}$. Naturforsch. 51c: $233-242$.

Kuru, P. (2014). Tamarindus indica and its health related effect. Asian Pac. J. Tropica Biomed 4(9): 676-681.

Fandohan, B., Assogbadjo, A.E., Kakaï, 
R.G., Kyndt, T., De Caluwé, E., Codjia, J.T.C. and Sinsin, B. (2010). Women's traditional knowledge, use value, and the contribution of tamarind (Tamarindus indica L.) to rural households' cash income in Benin. Economic Botany 64(3): 248-259.

Luzia, D.M.M. and Jorge, N. (2011). Antioxidant activity, fatty acid profile and tocopherols of Tamarindus indica L. seeds. Ciênc. Tecnol. Aliment., Campinas 31(2): 497-501.

Martinello, F., Soares, S.M., Franco, J.J., Santos, A.C., Sugohara, A., Garcia, S.B., Curti, C., Uyemura, S.A. (2006). Hypolipemic and antioxidant activities from Tamarindus indica L. pulp fruit extract in hypercholesterolemic hamsters. Food and Chemical Toxicology 44: 810-818.

Nahdi, M.S. and Kurniawan, A.P. (2019). Ethnobotanical study of medicinal plants in karst environment in Gunung Kidul, Yogyakarta, Indonesia. Nusantara Biosci. 11(2): 133-141.

Nwodo, U.U., Obiiyeke, G.E., Chigor, V.N. and Okoh, A.I. (2011). Assessment of Tamarindus indica extracts for antibacterial activity. Int. J. Mol. Sci. 12: 6385-6396; doi:10.3390/ijms12106385

Nwodo, U.U., Ngene, A.A., Anaga, A.O., Chigor, V.N., Henrietta, I.I. and Okoh. A.I. (2011b). Acute toxicity and hepatotoxicokinetic studies of Tamarindus indica extract. Molecules 16: 7415-7427; doi:10.3390/molecules16097415.

Obulesu, M. and Bhattacharya, S. (2011). Color changes of tamarind (Tamarindus Indica L.) pulp during fruit development, ripening, and storage. International Journal of Food Properties 14: 538-549.

Prabhu, K.H. and Teli, M.D. (2014). Ecodyeing using Tamarindus indica L. seed coat tannin as a natural mordant for textiles with antibacterial activity. Journal of Saudi Chemical Society 18: 864872.

Razali, N., Mat-Junit, S., Abdul-Muthalib, A.F., Subramaniam, S., and Abdul-Aziz, A. (2012). Effects of various solvents on the extraction of antioxidant phenolics from the leaves, seeds, veins and skins of Tamarindus indica L. Food Chemistry 131: 441-448.

Sumarni, W., Sudarmin, S., Sumarti, S.S. (2019). The scientification of jamu: a study of Indonesian's traditional medicine. J. Phys. Conf. Ser. 321: 032057.doi:10.1088/17426596/1321/3/032057.

Silalahi, M. and Mustaqim, W.A. 2020. Tumbuhan berbiji di Jakarta Jilid 1: 100 jenis-jenis pohon terpilih. UKI Press, Jakarta.

Silalahi, M. 2020. Gnetum gnemon L. Gnetaceae. In: Ethnobotany of the Mountain Regions of Southeast Asia, Ethnobotany of Mountain Regions. FM Franco (ed.). Springer Nature Switzerland AG 2020. doi.org/10.1007/978-3-03014116-5_121-1

Shahraki, M.R., Harati, M., and Shahraki, A.R. (2011). Prevention of high fructose-induced metabolic syndrome in male wistar rats by aqueous extract of Tamarindus indica seed. Acta Medica Iranica 49(5): 277-283. 